\title{
A 'haematoma sign' in flexor tendon injury
}

\author{
Friji Meethale Thiruvoth, Devi Prasad Mohapatra, Ravi Kumar Chittoria, Bibilash Babu
}

Department of Plastic Surgery, JIPMER, Puducherry, India

\section{Correspondence to}

Dr Devi Prasad Mohapatra, mohapatra.d@jipmer.edu.in

Accepted 4 November 2014

\section{CrossMark}

\section{To cite: Thiruvoth FM} Mohapatra DP, Chittoria RK, et al. BMJ Case Rep Published online: [please include Day Month Year] doi:10.1136/bcr-2014207246

\section{DESCRIPTION}

Open injuries or closed ruptures of tendons of the hand are seen in a variety of conditions. ${ }^{1}$ Prompt diagnosis for repair of these tendons is essential to achieve proper functional outcome. ${ }^{2}$ This necessitates early exploration and repair of the tendons under tourniquet control. Exploration and identification of the cut ends of the tendons are sometimes difficult, especially in the flexor tendon zone V due to their retraction into the adjacent adiposo-fascial layers. In such situations, searching for the tendon ends becomes tedious and time consuming. The 'haematoma sign' helps to identify the retracted tendon ends during exploration of tendon injuries of the hand. ${ }^{3}$

While exploring the tendon ends in a wound, the evidence of retracted tendon end(s) in the yellowish adipose-fascial soft tissue covering is the presence of a reddish or brownish haematoma (figure 1A). Exploration of this haematoma invariably reveals the tendon buried deeper, enmeshed within the synovial tissue covering it (figure 1B). Identification of this coloured indicator among the mass of structures helps in rapid identification of the tendon ends for repair. In a clinical series of 34 patients with flexor tendon injury at Zone $\mathrm{V}$ at our institute, the sign was present in all the tendons with ends buried within the synovial sheath.

The mechanism of this sign appears to be encasing of the cut end of the tendon in the overlying synovial sheath and bleeding from the end of the tendon that is entrapped in the sheath, which subsequently clots (figure 2). This sign is not seen in tendon ends that have not retracted inside the synovial sheath following trauma (figure 2).

Rapid identification of the tendon ends and repair is necessary and especially so when the

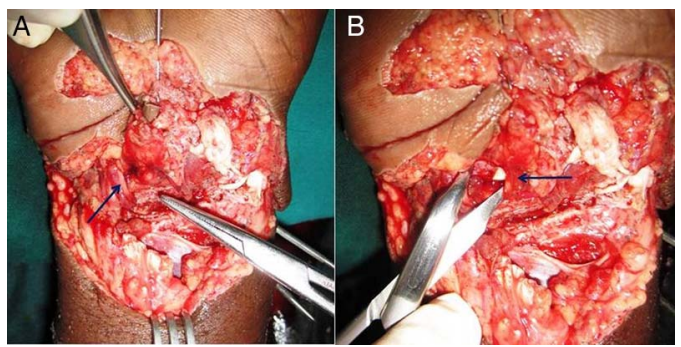

Figure 1 (A) Figure showing a reddish brown haematoma (arrow) at the site of tendon laceration; (B) deeper exploration reveals the pearly white tendon end.

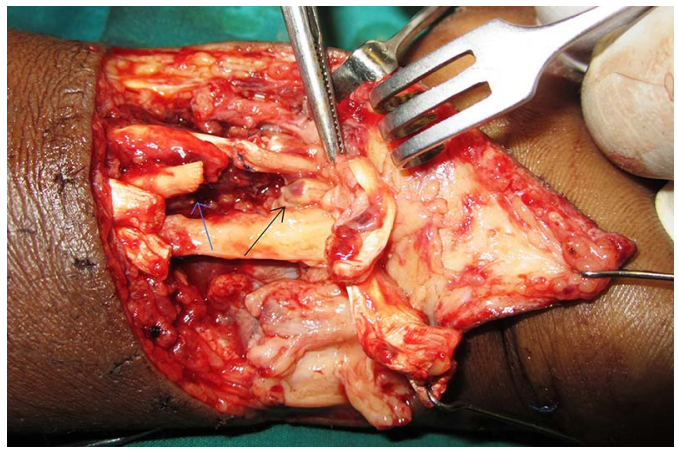

Figure 2 The 'haematoma sign' noticed in the distal retracted tendon end while the proximal unretracted ends do not show a similar sign.

exploration is being carried out under tourniquet control to avoid neuropathy following a prolonged exploratory session. An awareness of the 'haematoma sign' aids in such situations.

\section{Learning points}

- Open injuries or closed rupture of the tendons of the hand are seen in a variety of conditions.

- Exploration for and identification of the cut ends of the tendons for repair are difficult, especially in the flexor tendon zone $\mathrm{V}$ due to their retraction into the adjacent adiposo-fascial layers.

- Awareness of the 'haematoma sign' aids in rapid identification of tendon ends for repair among the mass of mangled tissues.

\section{Competing interests None.}

Patient consent Obtained.

Provenance and peer review Not commissioned; externally peer reviewed.

\section{REFERENCES}

1 David GW. Flexor tendon injuries and reconstruction. In: Mathes SJ, Hentz VR. eds. Mathes plastic surgery. 2nd edn. Philadelphia: Saunders Elsevier, 2006:359-82.

2 Zidel P. Tendon healing and flexor tendon surgery. In: Thorne $\mathrm{CH}$. ed. Grabb and Smith's plastic surgery. 6th edn. Wolter Kluwer/ Lippincott William Wilkins, 2007:803-9.

3 Smith P. Lister's the hand diagnosis and indications. 4th edn. Churchill Livingstone, 2002:90. 
Copyright 2014 BMJ Publishing Group. All rights reserved. For permission to reuse any of this content visit http://group.bmj.com/group/rights-licensing/permissions.

BMJ Case Report Fellows may re-use this article for personal use and teaching without any further permission.

Become a Fellow of BMJ Case Reports today and you can:

- Submit as many cases as you like

- Enjoy fast sympathetic peer review and rapid publication of accepted articles

- Access all the published articles

- Re-use any of the published material for personal use and teaching without further permission

For information on Institutional Fellowships contact consortiasales@bmjgroup.com

Visit casereports.bmj.com for more articles like this and to become a Fellow 